\title{
FEDERAL TAX POLICY AND THE ECONOMIC POSITION OF THE AGED
}

Who are the "aged"? They are the eighteen million Americans of sixty-five or over who make up over nine per cent of our nation's population. $^{1}$ Of these over ten million are women and almost eight million are men: 16.7 million are white and 1.4 million are non-white. ${ }^{2}$ Of those between the ages of sixty-five and seventy-four, 78.9 per cent of the men and 45.7 per cent of the women are married; of those over seventy-five, 57.1 per cent of the men and 20.2 per cent of the women are married. ${ }^{3}$ The three million people over sixty-five in 1900 will have increased to over twenty-five million by $1985 .{ }^{4}$

The objective of this Comment is to suggest a national policy for the economic problems of the aged and to propose specific statutory changes to effectuate this policy. Of course, the need for a new policy must first be established; this need will be demonstrated through an examination of the present financial position of the aged. The crux of the proposals to be offered is that the aged will receive greater assistance from the federal government but through more efficient channels than in the past. Both the social security machinery and the federal income tax will be utilized to this end.

1 Sixty-five is generally considered the retirement age in our society, and for this reason most statistics are keyed to that figure. For purposes of this Comment the term "aged" refers to those sixty-five or over. The use of age sixty-five as a line to distinguish the aged from the rest of the population is, of course, arbitrary. No magic transformation is known to take place on one's sixty-fifth birthday. However, for administrative reasons there must be a cut-off point, although the proposals and arguments set forth would still be valid if a different cut-off point were used.

2 U.S. Bureau of the Census, Dep't of Commerce, Current Populatton Reports, Series P-25, No. 321, Estrmates of the Population of The United States, By Age, Color, ANd Sex: July 1, 1960 to 1965, at 1, 11-12 (1965) [hereinafter cited as CuRrent Population Reports].

3 Current Population Reports, Series P-20, No. 144, Marttad Status and Fammy Status: March 1965, at 10-11.

4 The following table is a summary of past and projected population trends (population figures in thousands):

\begin{tabular}{lrrrrrrr} 
& 1900 & 1920 & 1940 & 1960 & 1965 & \multicolumn{1}{c}{1975} & \multicolumn{1}{c}{1985} \\
Total & & & & & & $218,855-$ & $247,953-$ \\
Population & 76,212 & 106,022 & 132,165 & 179,323 & 193,818 & 230,415 & 275,622 \\
65 or Over & 3,084 & 4,940 & 9,036 & 16,560 & 18,156 & 21,171 & 25,006 \\
Male & 1,558 & 2,488 & 4,418 & 7,503 & 7,931 & 8,923 & 10,279 \\
Female & 1,526 & 2,452 & 4,618 & 9,056 & 10,225 & 12,248 & 14,727
\end{tabular}

$\begin{array}{llllllll}\text { Population } & 4.1 & 4.7 & 6.8 & 9.2 & 9.4 & 9.1-9.6 & 9.1-10.1\end{array}$

Sources: 1900-1960 data: U. S. Bureau of the Census, Dep't of Commerce, Census of Population: 1960, Vol. I, Characteristics of the Population, Part 1, United States Sunmary 1-153-54 (1964); 1965 data: Current Population Reports, SERIEs P-25, No. 321, Estimates of the Population of the United States, By AGE, Color, AND Sex: JUly 1, 1960 To 1965, at 1, 11-12 (1965); 1975-1985 data: Current Population Reports, Series P-25, No. 286, Projections of the Population of the UNITED States, BY AGE AND SEX: 1964 To 1985, at 41-44. 


\section{Financial Position of the Aged}

This section of the Comment will present relevant statistics on the financial position of the aged which will aid in framing the problems that require legislative action. Figures on expenses and cash income of the aged will be presented along with those on their asset holdings.

The most useful and widely cited survey of the expenses of the aged was made in 1959 by the Bureau of Labor Statistics. ${ }^{5}$ It consists of twenty separate budgets for twenty different cities based on a "modest but adequate" standard. The figures range from 2,641 dollars to 3,366 dollars with an average of 3,041 dollars. $^{6}$ From this beginning the following yardsticks for a "modest but adequate" standard (which will be referred to as the BLS standards) have been adopted: a budget for a retired couple is 2,500 dollars and for a retired person living alone is 1,800 dollars. $^{7}$

The money income of the aged, which probably aggregates over forty billion dollars annually, ${ }^{8}$ is derived from a number of different sources. In 1962, thirty-two per cent of their income was from earnings (even though most of the aged do not work),,$^{9}$ thirty per cent from Old-Age, Survivors and Disability Insurance and fifteen per cent from interest, dividends and rents ${ }^{10}$-accounting for seventy-seven per cent of total income. ${ }^{11}$

The most significant figures on income are those which give the distribution among the income levels of families and persons over sixty-five. The following table is from the comprehensive 1963 Survey of the Aged undertaken by the Social Security Administration and sets forth the percentage of aged persons with various amounts of money income in $1962:{ }^{12}$

5 See Stotz, The BLS Interim Budget for a Retired Conple, 83 Monthly LaBoR REv. 1141 (1960).

6 Hearings Before the House Committee on Ways and Means on Medical Care to the Aged, 88th Cong., 1st \& 2d Sess. 217 (1964).

7 See, e.g., id. at 103 (testimony of Commissioner Ball), id. at 222 (testimony of Secretary Wirtz) ; Epstein, Income of the Aged in 1962: First Findings of the 1963 Survey of the Aged, Social Security Bull., March 1964, pp. 3, 8.

The original BLS figures are based on a couple renting a small house or apartment. A large part of the difference between the BLS average of $\$ 3,041$ and the quoted standard of $\$ 2,500$ is probably due to the fact that a majority of aged couples own their own homes. See ibid. and note 18 infra.

8 In 1961 the total income of the aged was $\$ 35$ billion. 1963 Presment's CouncII on Agrng ANN. REP., THE OLDER AMIERCAN 7 . It is safe to assume that it presently

9 Palmore, Work Experience and Earnings of the Aged in 1962: Findings of the 1963 Survey of the Aged, Social Security Bull., June 1964, pp. 3, 9.

10 Epstein, supra note 7, at 4.

11 The remainder was made up of other public benefits (6\%), public assistance $(5 \%)$, veterans' benefits $(4 \%)$, private pensions $(3 \%)$ and other sources $(4 \%)$. $45 \%$ of total income came from public sources. Ibid.

12 Epstein, supra note 7, at 8. Compare CuRrent Population Reports, Series P-60, No. 47, Incoume in 1964 of Families and Persons In the UNITEd STATES 24. 
Size of Money Income

$\begin{array}{lclc}\quad \text { (in dollars) } & \text { Married Couples }{ }^{\mathbf{3}} & \text { Men } & \text { Women } \\ \text { Less than 1000 } & 5 \% & 32 \% & 49 \% \\ 1000-1499 & 10 & 25 & 21 \\ 1500-1999 & 14 & 12 & 13 \\ 2000-2499 & 13 & 11 & 7 \\ 2500-2999 & 12 & 5 & 3 \\ 3000-3999 & 16 & 6 & 3 \\ 4000-4999 & 11 & 3 & 1 \\ 5000-9999 & 15 & 6 & 3 \\ 10,000 \text { and over } & 5 & 1 & -14 \\ \text { Median } & \$ 2,875 & \$ 1,365 & \$ 1,015\end{array}$

Matching these figures against the BLS standards, it appears that forty-two per cent of couples, approximately sixty-five per cent of unmarried men and approximately eighty per cent of unmarried women have cash incomes below the "modest but adequate" level. ${ }^{15}$

Using money income as the measure of the economic status of the aged does not present a complete picture. The aged, as well as the rest of the population, receive considerable non-cash income. Two important forms of non-cash income from the standpoint of the aged are the imputed income ${ }^{16}$ arising from home ownership and the gift income of saved living expenses received by those aged persons residing with their children. Unfortunately, figures on the non-cash income of the aged are not available and must therefore be disregarded for our purposes. The aged are also likely to dip into their assets ${ }^{17}$ to meet current needs. The "income" that would

13 At least one member sixty-five or over.

14 Less than $0.5 \%$.

15 The aged Negro is in an even worse position than his white counterpart. $51 \%$ of couples, $76.6 \%$ of unmarried men and $96.5 \%$ of unmarried women have incomes of less than $\$ 2,000$. Orshansky, The Aged Negro and His Income, Social Security Bull., Feb. 1964, pp. 3, 5.

16 See generally Vickrey, Agenda for Progressive Taxation 18-24, 401-06 (1947); Goode, Impnted Rent of Owener-Occupied Dwellings Under the Income Tax, 15 J. Finance 504 (1960).

it It is a common assumption that while the income of an aged person may be less than a younger person's, his asset holdings compensate for this and tend to equalize their positions. Unfortunately this is not true. The following summary shows that the asset holdings of most aged are not very significant: Couples

Unnarried

Per cent with non-home assets of less

than $\$ 1,000$

Per cent with non-home assets exceeding $\$ 15,000$

Median holdings of non-home assets for units who have them

Median holdings of financial assets

$37 \%$

$21 \%$

$\$ 6,180$

(those readily convertible into cash to meet emergency needs) for units who have them

Per cent with financial assets of less

See Assets of the Aged in 1962: Findings of the 1963 Survey of the Aged, Social See Assets of the Aged in 1962: Findin
Security Bull., Nov. 1964, pp. 3, 4-6. 
be generated from the conversion of assets (other than the equity in a home) ${ }^{18}$ into income prorated over the expected remaining life (in the form of an annuity) has been termed "potential income" and would increase the median income as follows: ${ }^{19}$

$\begin{array}{lcc} & \text { Money Income } & \text { Including } \\ \text { Only } & \text { Potential Income } \\ \text { Married Couples } & \$ 2,875 & \$ 3,130 \\ \text { Unmarried Men } & 1,365 & 1,560 \\ \text { Unmarried Women } & 1,015 & 1,130\end{array}$

Even under these figures thirty-six per cent of couples, approximately fifty-five per cent of unmarried men and approximately seventy-five per cent of unmarried women remain below the BLS standards. ${ }^{20}$

The financial situation of the aged in our society is far from secure, and many are in a precarious position. Under any political philosophy which would accept federal aid for a distressed segment of the population, this is a situation in which governmental action should be seriously considered. The Medicare Bill ${ }^{21}$ is a prime example of what the federal government has already done to lift part of the burden from the aged. On an individual level this legislation will probably result in a substantial decrease in the expenses of older persons. ${ }^{22}$ Other governmental programs, both local and federal, similarly increase the real income of the aged by providing goods and services they would otherwise have to purchase. Assuming that this is an area in which the federal government should act, it remains to consider specifically what has been done and, in the optimum, what can be done.

\section{A National Policy Toward the Aged A. Current Policy}

The government has had certain fairly consistent objectives in its policy toward the aged over the last thirty years. Wilbur Cohen ${ }^{23}$ has listed them as:

18 The equity of the aged in homes has been excluded because 1) the rental costs usually exceed the expense of home ownership and 2) the BLS standards assume the majority of the aged own their own homes. Murray, Potential Income From Assets: Findings of the 1963 Survey of the Aged, Social Security Bull., Dec. 1964, pp. 3-5.

Two-thirds of all aged couples own their own homes with a median equity of $\$ 10,100$, as do one-third of the unmarried with a median equity of $\$ 7,270$ for men and $\$ 9,070$ for women. Assets of the Aged in 1962: Findings of the 1963 Survey of the Aged, Social Security Bull., Nov. 1964, pp. 3, 5, 11.

19 Murray, supra note 18, at 3-5.

20 See id. at 5-7. 1965)).

2179 Stat. 286 (1965) (codified in scattered sections of 42 U.S.C. (Supp. I,

22 See Langford, Medical Care Costs for the Aged: First Findings of the 1963 Survey of the Aged, Social Security Bull., July 1964, p. 3.

$23 \mathrm{Mr}$. Cohen is the Undersecretary of Health, Education and Welfare. 
a. To increase income both absolutely and relatively,

b. To provide income on an insurance rather than an assistance basis,

c. To reduce the burden on relatives, charities, and general revenues of caring for the aged,

d. To provide basic underpinning through assistance on a needs test basis,

e. To recognize the special medical treatment needs of the aged, and,

f. To encourage the distribution of these costs over the aged person's lifetime. ${ }^{24}$

In 1961 a White House Conference on Aging was held. This conference, which had been planned since 1958, was really one in a series of conferences which had begun in 1950.25 The Conference Report called for a pluralistic approach to income maintenance-self-saving, private pensions and government programs of social insurance and assistance. ${ }^{26}$

The New Frontier's approach was aggressive. The President's 1963 Message on Aging ${ }^{27}$ marked the first time a President had sent a special message on the aged to Congress. ${ }^{28}$ The problems of the aged were to be attacked by every means within the Administration's power. In order to make the aged less dependent and to assign them a positive role in society, government intervention in every area, especially housing, health and income, was espoused.29 The Administration called for expanded local programs and bemoaned the lack of desire at both the national and local levels to spend the necessary money. ${ }^{30}$

The present Administration had high hopes of helping the aged in its War on Poverty. However, the head of the program recently admitted that there was very little the program could do for the over five million aged in "poverty" because its primary goal was to train the poor for productive work. ${ }^{31}$ This approach could not help the aged.

24 Cohen, Income and Tax Status of the Aged: Present Situation and Possible Modifications of Existing Policies, in 1 House CoMns. ON WAYs AND MEANS, 86ru Cong., 1st Sess., TAX Revision Compendium-Compendium of Papers on BroadENING tHe TAX BAse 539, 541-42 (Comm. Print 1959) [hereinafter cited as CoMPENDIUM].

25 See S. Rep. No. 247, 89th Cong., 1st Sess. (1965).

26 See Staff of Spectal Senate Comm. on Agrng, 87th Cong., 1st Sess., Basic Policy Statements and Recomamendations of the 1961 White House Conference on Agrng 12-13 (Comm. Print 1961).

27 H.R. Doc. No. 72, 88th Cong., 1st Sess. (1963).

28 See S. REP. No. 247, 89th Cong., 1st Sess. (1965).

20 See Kent, Aging and Govermment Policy: Outlook for Progress in the 1960's, in Agrng ANd the Economy 195 (Orbach \& Tibbets ed. 1963).

$30 \mathrm{Id}$. at 205-07.

31 Testimony of Sargent Shriver before the Senate Special Committee on Aging, N.Y. Times, Jan. 20, 1966, p. 21, col. 4. 
Last year Congress passed the Older Americans Act of $1965,{ }^{32}$ which included in its declaration of objectives "an adequate income in retirement in accordance with the American standard of living" and "freedom, independence, and the free exercise of individual initiative in planning and managing their own lives." ${ }^{33}$ The act also set up an Administration on Aging within the Department of Health, Education and Welfare, to which various functions were assigned. ${ }^{34}$

The general objectives of government policy toward the aged have remained fairly constant since 1935 ; and since 1960 there has been a trend toward a greater number of programs and a more activist philosophy in attacking problems. Both the Executive and Congress have been keenly aware of the problems and politics of the aged.

\section{B. A Suggested Policy}

Once it is decided that there should be an affirmative national program to improve the economic position of the aged, the ultimate objective should be to provide each person with sufficient income to enjoy his later years in a comfortable manner and to allow him to spend this income in the way he desires. This is basically similar to our enunciated present policy except for the advocacy of "sufficient income" as a definite standard. The exact dollar level should be flexible and could be based on five year periodic studies by an assigned agency.

In striving for this horizon, certain principles should be used as the guiding stars. First, and very important, is that self-preparation for retirement be encouraged..$^{35}$ People are happier when they are not dependent

3279 Stat. 218 (1965), 42 U.S.C. $\$ \$ 3001-53$ (Supp. I, 1965).

3379 Stat. 219 (1965), 42 U.S.C. $\$ 3001$ (Supp. I, 1965).

34 See 79 Stat. 220 (1965), 42 U.S.C. §3011-12 (Supp. I, 1965).

35 The term "self-preparation" most commonly refers to the situation where an individual puts part of his present earnings away in some form (savings or investment) for utilization when his working days are over. "Self-preparation" should also include private retirement plans. The original plan and improvements in it are often received by the employees in lieu of wage increases and can be said to reflect a choice to defer present earnings to the future. See generally BERNSTEIN, THE FUTURE OF Private Pensions (1964); McGil, Fundamentals of Private Pensions (2d ed. 1964); Bankers Trust Co., 1960 Study of Industrial Retrement Plans; President's Committee on Corporate Pension Funds and Other Private Retirement and Welfare Programs, Public Policy and Private Pension Programs (1965).

Private retirement plans have been afforded special tax treatment by Congress. See INT. REv. CoDE of 1954, \$\$ 401-05, 501 (a); Treas. Regs. $\$ \$ 1.401-05$ (as amended); Strecker, Taxation of Retirement Provision, 27 LAW \& ConTEMr. PROB. 67, 70-78 (1962). See also Macaulay, Fringe Benefits and Their Federal Tax TreatMENT 102-24 (1959); Strecker, supra at 84-88.

In 1963, 23.8 million workers constituting almost $46 \%$ of the private labor force were covered by private plans, and 2.3 million beneficiaries received 2.46 billion dollars. Reserves of private plans amounted to 69.9 billion dollars. See Skolnik, EmployeeBenefit Plans: Developments, 1954-63, Social Security Buil., April 1965, pp. 4, 7, 11. Projections for the future indicate that by 1970,34 million workers will be covered by plans with reserves of 125 billion dollars, and in 1980 these figures will reach 42.7 million and 225 billion respectively. Approximately $60 \%$ of all workers will be covered by private plans in 1980 . See PRESIDENT's CommitTeE on CoRporate PENSION 
on others, including government, for their basic needs. They are also more responsible in a political sense. This avoids the "welfare state of mind," which strips the individual of his self-respect. ${ }^{36}$ An even more important reason for encouraging self-preparation is to allow a higher standard of living during the later years. Even if the income of the aged is raised by some public program, it will probably still be less than the average income during the working years. ${ }^{37}$

A second principle is that the government should assure every aged person a minimum level of income. Society today will not let people starve to death; so in effect we are providing a subsistence level of income, and the gap between subsistence and "adequate but modest" is one that common decency demands be filled. Because of the inability of the aged to compete in the labor market, there would be no aura of giving money to "lazy good-for-nothings" who should be working. In light of our recognition of the special problems of the aged and our general refusal to allow anyone to live below a subsistence level, the idea of government assurance of a minimum level of income is not a startling innovation but only a natural extension of what has gone before. ${ }^{38}$

A third principle is not to penalize those who have tried to provide for themselves. ${ }^{39}$ The wider the gap between the target level of income

Funds and Other Private Retrrement and Welfare Programs, Public Policy and Private Pension Progrants App. A, tables 1 \& 2 (1965).

A self-employed person is in a special situation. If he is a member of a group that could qualify as a "corporation" under INT. REv. CODE OF 1954, §7701(a) (3), he could receive the same treatment as a corporate employee. But see Treas. Reg. $\$ 301.7701-1$ \& 2 (1960), as amended, T.D. 6797, 1965-1 CuM. Burc. 553, which makes it almost impossible for professional corporations to qualify for corporate tax status. See also Bittker, Professional Associations and Federal Income Taxation: Some Questions and Comments, 17 TAx. L. Rev. 1 (1961); Wolfman \& Price, Qualifying Under Final Kintner Rules Will Be Difficult in Most States, 14 J. TAXatron 105 (1961).

In 1962 Congress passed the Self-Employed Individuals Tax Retirement Act, 76 Stat. 809 (codified in scattered sections of INT. REv. CODE of 1954) (long known as H.R. 10 or the Keogh Bill), which was intended to give the self-employed a measure of equality with corporate officers and employees as to the taxation of retirement benefits. See generally Grayck, Tax Qualified Retirement Plans for Professional Practitioners: A Comparison of the Self-Employed Individuals Tax Retirement Act of 1962 and the Professional Association, 63 Conum. L. Rev. 415 (1963); Rapp, The Self-Employed Individuals Tax Retirement Act of 1962, 18 TAX L. REv. 351 (1963) ; Snyder \& Weckstein, Quasi-Corporations, Quasi-Employees and Quasi-Tart Relief for Professional Personts, 48 CORNeLl L.Q. 613 (1963).

36 See note 64 infra.

37 In 1963 the average income of families with the head over sixty-five was $54 \%$ of that of families with the head under sixty-five. See CURRENT Population Reports, SERIES P-60, No. 46, INCOME of THE ELDERLY IN 1963, at 1 (1965).

38 See Report of the National Comarission on Technology, Automation, AND Economic Progress, TECHNology AND THE AMERICAN Economy 38-41, 110 (1966), which said the federal government should guarantee every American family a minimum annual income.

39 For example, assume $A$ and $B$ both earn $\$ 4,000$ a year with all else equal except that $A$ spends it all and $B$ saves $\$ 500$ a year. Both retire at sixty-five. Without public assistance $B^{\prime}$ 's retirement income will be considerably higher than $A^{\prime}$ s. But if $A$ is given extra assistance because his income is less than the minimum level while $B^{\prime}$ s income is exactly at the minimum level, $B$ is being penalized for his efforts because during his earning period he had less spending money than $A$. 
and the average retirement income, the more acute the problem will be. It would be unfair to the person who by his own savings is able to provide himself with the full amount of income, for his neighbor, who did not provide for himself, to receive public monies. This would not only be inequitable, but would probably lessen the incentive for self-saving.

This concern leads to a fourth principle-not to give unneeded benefits to the wealthy. No program that purposefully did this could be justified. Given this evil and the one just discussed, the problem is to find the best way to deal with both. Because there are fewer wealthy aged than those close to the minimum income level, and because it is relatively easy to skim the cream off the top, it is preferable to deal with the wealthy aged separately. Specific proposals on this subject will be made in the section on tax changes.

As a last guiding principle there should be a conscious effort to limit the role of the government. Although improving the financial condition of the aged will require large government expenditures, it does not follow that government controls over their lives must occur. ${ }^{40}$ The more the role of the government is purely supervisory, the more likely is the ultimate goal of free choice to be achieved.11 The government has another important function it can perform here-to conduct research on gerontology and to provide the necessary statistics so that any significant changes in the general situation of the aged can be spotted.

As a unit, these five principles would guarantee to almost every aged person a minimum income level so that he could live comfortably without government interference, and would encourage people in self-saving without giving a windfall to the wealthy.

\section{Alternative Means of Implementing Suggested National Policy}

\section{A. Propriety of Affording Special Treatment to the Aged}

Before any particular means are discussed, it is necessary to establish the propriety of any separate treatment for the aged. Our society will not allow anyone in need to starve or otherwise lack the basic necessities of life -it guarantees everyone a subsistence level of existence. It is on the issue of giving aid beyond the subsistence level to the aged that there is significant dispute. ${ }^{42}$

The opponents of special treatment argue that it is unfair and unjust to treat the aged differently solely on account of their age and that any

40 Of course huge government expenditures are also a concern, but at least they are not made unless Congress has made an express decision that such expenditures are in the general welfare.

41 But see Kent, supra note 29, at 201.

42 Of course, there are those who are against any aid at all. 
aid should be given to all the poor. ${ }^{43}$ These are the same people who generally favor a greatly expanded role for the federal government. ${ }^{44}$

This opposition could be handled by agreeing that the government should aid all the poor but denying that this is a sufficient reason for not helping the aged. ${ }^{45}$ It could also be handled tactically by calling attention to the precedential value of special aid to the aged for programs for all the poor. ${ }^{46}$ However, considering the question on its merits alone, it is clear that there are valid reasons for singling out the aged. The basic question is whether we want those over sixty-five without sufficient income to attempt to earn income they need. The answer is that for most of them it is a physical impossibility. ${ }^{47}$ In contrast, the "younger poor," except those with physical or mental infirmities, are potentially capable of earning the income they need. 48 A second answer is that most of society would not want to force the aged to work, even if they were capable of it. Some people feel this way as part of the notion that the aged have played the game already and are now entitled to a little special treatment; others just want to keep them out of the labor market so more jobs for younger workers will be available.

Proceeding from the premises that it is proper to give the aged as a group special treatment beyond that given to other poor groups and that the BLS standards are somewhat above a subsistence level and represent desirable minimum standards, ${ }^{49}$ certain observations follow: to the extent that this subsistence level exceeds the actual income level of the aged, ${ }^{50}$ the gap is being filled by money or substitute services coming from somewhere, and, to the extent the BLS standards exceed either level, people are living in a condition of which society does not approve. The natural conclusion is that every aged person should receive income up to the BLS level..$^{51}$ The next sections will explore the possible methods of providing them with this income. ${ }^{52}$

43 See Burns, Taxation of the Aged: Retirement Income Credit and the Like, 1 CoMPENDIUM 551-52.

44 See, e.g., Harrington, The Other America 170-71 (1962); Kent, supra note 29 , at 201 .

45 Cf. Railway Express Agency, Inc. v. New York, 336 U.S. 106, 110 (1949): "It is no requirement of equal protection that all evils of the same genus be eradicated or none at all."

46 See Burns, supra note 43 , at 555.

47 See statement of Sargent Shriver before the Senate Special Committee on Aging, N.Y. Times, Jan. 20, 1966, p. 21, col. 4.

48 This distinction will also affect the type of aid given whether it be for subsistence or beyond it. Programs of a temporary nature which benefit the recipient while preparing him for reentry into the labor market (e.g., retraining and relocation) can be used for younger people but are not suitable for the aged.

49 The BLS standards are not sacred, and there can be no objection to using different figures. Whatever figures are used must be subject to change as conditions change.

50 See text accompanying notes 12-15, 19 supra.

51 Cf. Report of the National Commission on TeChnology, Automation, and Economic Progress, op. cit. supra note 38 , at $38-41,110$.

52 Irrespective of which method is chosen, the economic consequences of providing the aged with additional income must be kept in mind. There will be a deflationary effect from the withdrawal of funds from the economy, but this will not be enough 


\section{B. Old-Age, Survivors and Disability Insurance}

Old-Age, Survivors and Disability Insurance ${ }^{53}$ (OASDI), a part of the Social Security Act, ${ }^{54}$ is a federally administered program providing "protection to workers and their families against loss or stoppage of earnings resulting from retirement in old age, death, and disability." 55 Coverage under OASDI is not universal but rather is conditioned on attachment to the labor market. Today, more than ninety per cent of those gainfully employed are covered. ${ }^{58}$ Benefits ${ }^{57}$ are paid as a matter of right to anyone who is eligible ${ }^{58}$ and are not dependent on a means test. Today, over

to counter the inflationary effect of giving a large quantity of money to a high consumption group such as the aged, and, if the net effect is heavily inflationary, the whole project might be defeated because of the higher cost of living for the aged.

5349 Stat. 622 (1935), as amended, 42 U.S.C. $\$ \$ 401-25$ (1964), as amended, 42 U.S.C. $\$ \$ 401-27$ (Supp. I, 1965).

5449 Stat. 620 (1935), as amended, 42 U.S.C. $\$ \$ 301-1394$ (1964), as amended, 42 U.S.C. $\$ \$ 302-1396$ (d) (Supp. I, 1965).

55 Schottland, The Social Security Program in the United States 41 (1963). 56 Social Security Bu1l., 1963 Annual Statistical Supp., table 19, at 24.

Initially, under the 1935 act and the 1939 amendments, coverage was limited to employees in non-agricultural industry and commerce. In 1950, coverage was extended to 4.5 million self-employed, to 650,000 farm workers and to federal employees not covered under the Civil Service Retirement System, and a group option was extended to some state and local government officials for a total increase in coverage of 8.7 million. In 1951, the Railroad Retirement Act was, in effect, joined with OASDI; in 1954, 2.5 million self-employed farmers and 850,000 more farm workers were brought under along with other extensions including an individual option to ministers to elect coverage, and, in 1956, coverage was extended to the armed forces. See Waldman, Coverage Extension Under Old-Age, Survivors, and Disability Insurance, Social Security Bull., June 1961, p. 3. In 1965, doctors, the group which had fought social security the hardest, were finally brought under the umbrella. See 79 Stat. 391 (1965), 42 U.S.C. \$411(c) (5) (Supp. I, 1965). It was estimated that 170,000 doctors would be covered. S. REP. No. 404, 89th Cong., 1st Sess. 111 (1965).

The major groups excluded from coverage today are federal government employees if they are covered under another federal retirement system, some state and local government employees and certain farm and domestic workers with very low incomes. See Social Security Bull., 1963 Annual Statistical Supp., table 19, at 24.

57 There are two other benefits, besides the old-age benefit payable to the retired worker himself, which are relevant to this discussion. One is the "wife's insurance benefit," payable, in an amount equal to $50 \%$ of the husband's primary benefit, to the wife of a covered worker who is at least sixty-two years old and not covered herself. The second is the "widow's insurance benefit," payable, in an amount equal to $821 / 2 \%$ of the husband's primary benefit, to widows over sixty of covered workers.

58 To be eligible for retirement benefits, a person must have insured status, which today means he must have forty quarters of coverage (prior tests were less to cover older people who had done most of their work prior to the act), must be sixty-two years old (the normal retirement age is sixty-five but actuarially reduced benefits can be received starting at age sixty-two) and must be actually retired. This last requirement is enforced by an earnings test which provides that any earnings over $\$ 1,500$ of an otherwise eligible person under seventy-two reduce his benefit payment. For every two dollars in earnings between $\$ 1,500$ and $\$ 2,700$, benefits are reduced by one dollar, and for every one dollar of earnings over $\$ 2,700$, benefits are reduced by one dollar. A beneficiary does receive full benefits in any month his wage earnings are less than $\$ 125$ or in which he does not render substantial self-employment services. 79 Stat. 380 (1965), 42 U.S.C. $\$ \$ 403$ (b), (f) (Supp. I, 1965). See Myers, Earnings Test under Old-Age, Survivors, and Disability Insusrance: Basis, Background, and Experience, Social Security Bull., May 1964, p. 3.

A floor amendment to the recent Tax Adjustment Act of 1966, 80 Stat. 38 (1966), extended retirement benefits of $\$ 35$ per month to uninsured individuals who are at least seventy-two years of age. The benefits payable are to be reduced by the amount of benefits received from any other governmental pension system and are not to be paid at all in any month where the individual receives payments from a federally approved state plan based on need. 80 Stat. 67-70 (1966). 
eighty per cent of those people of sixty-five or over are eligible to receive benefits, and over ninety per cent of those now reaching sixty-five are eligible to draw benefits. ${ }^{59}$ Benefits are based on a worker's average monthly earnings with the lower-income workers receiving a higher percentage of their earnings. OASDI is financed by a payroll tax in equal proportion on the employer ${ }^{60}$ and the employee, ${ }^{61}$ with the self-employed paying a rate of 150 per cent of that paid by the employee. ${ }^{62}$

OASDI is neither a pure insurance program nor a pure income maintenance program, but rather a hybrid commonly referred to as social insurance. The principle of social insurance is that payments are made to an eligible claimant as a matter of right as opposed to the means and needs test used in dispensing relief. ${ }^{83}$ Social insurance thus avoids the psychological impact of receiving charity, which undermines the recipient's selfrespect and independence. ${ }^{64}$ Whatever the real nature of social insurance, ${ }^{65}$

59 It is projected that in $1970,85 \%$, in $1980,89 \%$, and in the long run $95 \%$ of those sixty-five or over will be eligible to receive benefits. See SPECIAL Senate Comm. on Aging, 87th Cong., 2d Sess., Background Facts on the Financing of the Health Care of the Aged 16 (Comm. Print 1962).

60 See INT. REv. Code of 1954, § 3101 (a).

61 See INT. REv. Code of 1954, §3111(a).

62 Both the base on which the tax is levied and the rate of tax were increased by the Social Security Amendments of 1965 , which also imposed a separate but similar $\operatorname{tax}$ to finance the Medicare program. The base was raised from $\$ 4,800$ to $\$ 6,600$. See INT. REv. Code of 1954, $\$$ 1402(b), 3121. For the new rate structure see INT. REv. CODE OF 1954, \$\$1401(a)-(b), 3101 (a)-(b), 3111(a)-(b).

The system is more of a pay-as-you-go rather than a full reserve one, but the Advisory Council on Social Security considers it soundly financed and warns that if income greatly exceeds outgo, it would have a deflationary effect on the economy. See Report of the Advisory Council on Social Security: The Status of the Social Security Program and Recommendations for Its Improvement, Social Security Bull., March 1965, pp. 3, 5. Given the premise that the system will not cease to exist, it is in no financial danger.

63 See ten Broeck \& Wilson, Public Assistance and Social Insurance-A Normative Evaluation, 1 U.C.L.A.L. REv. 237, 244 (1954) ; Note, Charity Versis Social Insurance in Unemployment Compensation Lazes, 73 YALE L.J. 357, 359-63 (1963).

64 It is commonly thought that the self-respect of a person is undermined by the receipt of charity but that it is not similarly affected by the receipt of benefits which have been earned. However, there is no empirical data to back this up. See Note, 73 YALE L.J. 357, 362 \& nn.25-26 (1963). Notwithstanding the lack of empirical data, the fact that this belief has persisted and is widely accepted is strong evidence of its validity. Mr. Justice Black in his dissent in Flemming v. Nestor, 363 U.S. 603, 623 (1960), quoted the statement of Senator George, the chairman of the Finance Committee at the time the Social Security Act passed, from 102 CoNG. REc. 15110 (1956), where he said the principle of social insurance "comports better than any substitute we have discovered with the American concept that free men want to earn their security and not ask for doles-that what is due as a matter of earned right is far better than a gratuity." Professors ten Broeck and Wilson stated the distinction between means test aid and aid as of right in sharp terms:

Means test aid ... strikes at the vital foundations of our political system: at the dignity and worth of the individual . . a at the psychological foundations of men: at their need for security, self-esteem, social approval and independence; at the gratification of those common and basic needs which are an indispensable concomitant of emotional well-being.

Aid as of right moves in the opposite direction. It strengthens freedom, property, dignity and equality.

ten Broeck \& Wilson, supra note 63, at 298.

65 See ten Broeck \& Wilson, supra note 63, at 245-51. See generally ibid. 
it is safely ensconced in the minds of the populace as an "insurance system with a heart" rather than a dole.

The present level of benefits is below the BLS standards despite the seven per cent increase in benefits in $1965 .{ }^{66}$ To use OASDI to provide more income for the aged would, of course, involve increasing payroll taxes substantially. There is a point when the combined employer-employee taxes will become too burdensome, politically or economically, although no one knows where that point is. There was some talk that ten per cent was the limit, ${ }^{67}$ but under the present schedule that level will be reached by the combined OASDI and medicare tax in 1973.68 Another objection to using OASDI is that many of those aged persons who need income the most are not covered. So if OASDI is used, it will only be able to handle part of the job. Finally, since OASDI is paid as of right, there is the danger of giving unneeded benefits to the wealthy among the aged.

\section{Direct Subsidy}

Another method of providing the aged with more income would be to pay those with incomes below the BLS standards the amount necessary to bring them up to that level. A direct federal program could be established, or the current Old-Age Assistance Program ${ }^{69}$ could be expanded. Under OAA, a part of the Social Security Act, federal grants are made to states which have established old age assistance programs that meet certain federal standards. Speaking generally, this program compliments OASDI by providing income for those indigent aged ineligible under OASDI or whose benefits under it are inadequate. Because this is basically a state program, the level of payments and eligibility requirements vary widely among states.

The main objections to using a relief program to provide aid-the forms of procedure and control that are used ${ }^{70}$ and the stigma of dependency that attaches to the recipient ${ }^{71}$-have already been discussed in contrasting relief with social insurance. Whether this has to be the manner

86 There are two schools of thought as to the amount of income that should be provided by OASDI. See BERNSTEIN, op. cit. supra note 35, at 187-90. One looks upon it to provide solely a basic floor of protection against dependence, whereas the other says it should support a much higher level of income-one that allows a more adequate style of living. Compare, e.g., Marshall, Social Security at the Crossroads, 14 IND. \& LAB. REL. Rev. 113, 115 (1960), with, e.g., remarks by Senator Robert Kennedy, N.Y. Times, Oct. 28, 1965, p. 21, col. 5 (city ed.).

Apparently the original Congressional view in 1935 supported the latter approach.

See BERNSTEIN, op. cit. supra note 35 , at 189 .

67 See, e.g., 1964 Medicare Hearings 86-88.

68 See INr. REv. CoDE of 1954, §\$ 3101 (a)-(b), 3111 (a)-(b).

6949 Stat. 620 (1935), as amended, 42 U.S.C. $\$ \S 301-306$ (1964), as amended, 42 U.S.C. $\$ \S 302-03,306$ (Supp. I, 1965). See generally ScHotTLAND, op. cit. supra note 55, at 96-109.

$7^{0}$ See Reich, Individual Rights and Social Welfare: The Emerging Legal Issues, 74 YALE L.J. 1245, 1246-51 (1965); Reich, Midnight Welfare Searches and the Social Security Act, 72 YaLe L.J. 1347 (1963).

71 See note 64 supra and accompanying text. 
in which public assistance is operated has been questioned, ${ }^{72}$ but it is unlikely that the public's views on the subject will change in the near future. This alone is probably enough to veto a complete program of aid through direct relief, but there is the additional reason that such a program would be unfair to the person who by his own savings is able to provide himself with sufficient income to meet the BLS standard level. ${ }^{73}$

\section{Relief Through the Tax System}

Given the present income of the majority of the aged, it is obvious that the amount of aid that can be given them through the present tax system is limited. ${ }^{74}$ While the income tax as we know it needs income on which to operate, there have been a number of proposals made recently for a "negative income tax" 75 which in essence is a welfare program using the federal income tax system to distribute and measure the amount of aid given. Most of the plans proposed under this general term are incentivetype plans intended to encourage the recipients to earn income and as such are not particularly well suited for the aged. ${ }^{76}$ A non-incentive plan, one simply making direct payments to people with taxable incomes below the basic allowance, is nothing more than a direct relief program subject to the objections discussed above.

Provisions in the current tax laws which give preferential treatment to the aged include an additional exemption of 600 dollars allowed a taxpayer who has attained the age of sixty-five before the close of the taxable year. ${ }^{77}$ A second preference is the exclusion of social security benefits, allowed by

72 See Reich, Social Welfare in the Public-Private State, 114 U. PA. L. Rev. 487 (1966).

73 See note 39 supra.

74 Unless total net income is included in the tax base and no deductions are allowed, the tax system is being used to further some economic, fiscal or social policy of the government. We have never had a pure net income tax and undoubtedly never will. But see S. 3250, 88th Cong., 2d Sess. (1964) (The Iong Plan for a Simplified Tax System). Moreover, today the government openly declares that the tax system should be used as an instrument of policy. See Address by Undersecretary of the Treasury Fowler at the Fourteenth Annual Midyear Conference of the Tax Executives Institute in Washington, March 2, 1964; Address by Assistant Secretary of the Treasury Surrey on the Role of Tax Policy in the Great Society to Financial Analysts Federation Conference in Washington, Oct. 5, 1965.

75 See, e.g., Reagan, Washington Should Pay Taxes to the Poor, N.Y. Times, Feb. 20, 1966, \$6 (Magazine), p. 24; Tobin, On Improving the Economic Stativs of the Negro, 94 DaEdalus 878, 889-95 (1965). The Poverty Program is said to be considering such a plan, see N.Y. Times, Dec. 15, 1965, p. 1, col. 1, and the National Commission on Technology, Automation, and Economic Progress suggested that Congress give "serious study" to such a plan. Natronal CoMmission on TECHNology, Automation, and Economic Progress, Technology and the American Economy 40-41 (1966).

${ }^{76}$ See Reagan, supra note 75; Tobin, supra note 75, at 891; N.Y. Times, Dec. 19, 1965, p. 41, col. 3 (plan of Milton Friedman).

Professor Tobin's plan specifically excludes OASDI beneficiaries on the ground that Congress should provide them with minimum benefits through that system.

77 Int. Rev. Code of 1954, §151(c). In 1963, when President Kennedy unsuccessfully proposed its repeal, H.R. Doc. No. 43, 88th Cong., 1st Sess. 12 (1963), the cost of this provision was estimated at $\$ 380$ million annually. Hearings Before the House Committee ont Ways and Means on the President's 1963 Tax Message, 88th Cong., 1st Sess., pt. 1, at 217 (1963) [hereinafter cited as 1963 Tax Hearings]. 
administrative ruling since $1941 .^{78}$ Moreover, neither the employer's contribution nor the interest income earned on the Social Security Trust Fund is taxed to the employee. Thirdly, the retirement income credit allows certain taxpayers sixty-five or over to offset their tax by a credit based on a percentage of "retirement income," 79 the intent of the section being to give a rough sort of tax parity to those aged persons receiving tax-exempt social security and those receiving taxable income. ${ }^{80}$ Although changes should be made in these provisions, ${ }^{81}$ these changes will not solve the problem of inadequate income, which is beyond the tax system's ability to solve. ${ }^{82}$

\section{E. Contributions by Relatives}

Another possibility would be contributions by relatives. Assuming a statute ${ }^{83}$ requiring that children contribute to the support of their parents

78 I.T. 3447, 1941-1 Cum. Burc. 191. Although the exclusion is by administrative grace, the fact that it has been in effect for twenty-five years gives it congressional imprimatur, and any change would probably have to come from that body.

79 INT. REV. Cone of 1954, §37. Basically, any taxpayer who had earned income of $\$ 600$ or more for any ten years prior to the taxable year and who received "retirement income" (defined as pensions and annuities, interest, dividend, rent and certain bond income) during the taxable year can offset his tax by a credit based on a percentage $(15 \%)$ of retirement income. There is a limit on retirement income of $\$ 1,524$ (the maximum old-age benefit payable to one person under social security prior to the 1965 amendments) less social security and railroad retirement benefits. Taxpayers under sixty-two also have to subtract earned income over $\$ 900$, and those sixty-two to seventy-two have to subtract one-half of earned income between $\$ 1,200$ and $\$ 1,700$ and all earned income over $\$ 1,700$. This corresponds to the pre-1965 earnings test under OASDI. See Myers, sipra note 58, at 9 . The annual revenue loss caused by the credit is estimated at $\$ 135$ million. 1963 Tax Hearings, pt. 1, at 217. 69 (1962).

80 Strecker, Taxation of Retirement Provision, 27 LAW \& Contemp. Prob. 67,

There are several other tax provisions keyed to the aged. For taxable years beginning after December 31,1966 , aged taxpayers will receive no preference on the deduction of medical and drug expenses. However, for taxable years beginning prior to January 1, 1967, if either the taxpayer or his spouse is sixty-five, the $3 \%$ floor on the deduction of medical expenses is not applicable to them, INT. REV. CODE OF $1954, \S 213$ (a) (2), nor is the additional $1 \%$ floor on the deduction of drug expenses, INT. REv. CODE OF 1954, $\S 213$ (b), but there is a ceiling on the maximum deduction that may be taken. INT. REv. CoDE of 1954, $\$ 213(\mathrm{~g})$.

A new provision, INT. REv. CODE of 1954, $\$ 121$, added by the Revenue Act of 1964 , grants a taxpayer who is sixty-five or over an election to exclude from gross income the gain from the sale or exchange of property which the taxpayer had used as his principal residence for five of the last eight years preceding the sale. (This exemption operates independently of the separate non-recognition provision, INT. REV. CODE of 1954, § 1034, which provides that gain from the sale of a principal residence need not be recognized if a new principal residence is purchased within one year from the date of sale. The basis of the new residence is reduced by the amount of nonrecognized gain.) Where the adjusted sales price exceeds $\$ 20,000$, the exclusion under $\$ 121$ is limited to the amount of gain multiplied by $(\$ 20,000 /$ adjusted sales price). This section should be repealed. The gain on the sale of a residence already receives favorable treatment by being taxed at capital gains rates, see INT. REv. CoDE of $1954, \$ \S 1202,1221,1222$, and the haphazard nature of such gain indicates that this provision has little effect on the current income of homeowners.

81 See pp. 1239-42 infra.

82 Cf. Wolfman, Federal Tax Policy and the Support of Science, 114 U. PA. L. REv. 171 (1965), for an analysis in the area of science of the advantages and disadvantages of using the tax system, as opposed to direct Congressional appropriations, to achieve a given objective.

83 At common law a child had no obligation to support his parents. Department of Mental Health v. Kirchner, 60 Cal. 2d 716, 718 n.4, 388 P.2d 720, 721 n.4, 36 Cal. 
would be constitutional, ${ }^{84}$ the wisdom of passing such a statute is doubtful. Besides being neither financially ${ }^{85}$ nor administratively feasible, it runs counter to the tide of social welfare programs that have put much of the responsibility on the state rather than the family. ${ }^{86}$

\section{A Recommended Program}

\section{A. Proposal to Raise the Income of the Aged}

It is proposed that the federal government match one-half of the oldage, wife's insurance and widow's insurance benefits payable to a retired worker or his spouse. This plan would be coordinated with both the Railroad Retirement ${ }^{87}$ and Federal Civil Service Retirement plans, ${ }^{88}$ even though both of these plans require a higher contribution rate and pay larger benefits than OASDI, but the actual dollar amount of payments would not exceed that made through OASDI. Payments under OAA to those aged persons still eligible under the program ${ }^{80}$ would be increased by fifty per cent. In order to integrate these payments with the earnings test under

Rptr. 488, 489 n.4 (1964), vacated and remanded, 380 U.S. 194, remittitur accordingly, 62 Cal. 2d 586, 400 P.2d 321, 43 Cal. Rptr. 329 (1965). The purpose of the first relative responsibility law in 1597 was to minimize the cost to the public. See ten Broeck, California's Dual System of Family Law: Its Origin, Development, and Present Status, 16 Stan. L. Rev. 257, 283 (1964).

84 Forty-two states, Puerto Rico and the District of Columbia have statutes requiring a child to pay for the care given a parent committed to a state mental institution. Department of Mental Health v. Kirchner, supra note 83, 380 U.S. at 201 n.8. These statutes have generally been held constitutional. See 39 NoTRE DAME LAw. 723, 724-25 (1964). But cf. Department of Mental Health v. Kirchner, supra note 83 , where such a statute was held a denial of California's equal protection clause. For critical comment on the court's use of equal protection, see 63 MICE. L. REv. 562 (1965); 39 N.Y.U.L. REV. 858 (1964).

85 Children who are financially able to contribute to the support of needy parents would probably do so with or without laws, and any money forced out of children who are not financially able to contribute to their parents denies them the right to use their small surplus income for self-advancement. The family relationship would be disrupted rather than strengthened. See Schorr, Filial Responsibility and the Aging, or Beyond Pluck and Luck, Social Security Bull., May 1962, p. 4. In 1962, only $3 \%$ of aged couples and $5 \%$ of unmarried aged received cash contributions from relatives not living in the same household. Epstein, Income of the Aged in 1962: First Findings of the 1963 Survey of the Aged, Social Security Bull., March 1964, pp. $3,6$.

86 The four suggestions just discussed are the most significant of the possible sources of income for the aged. It is assumed that the aged are unable to generate the necessary income themselves. Neither their assets, see note 17 sipra, nor their earning potential is up to this task. Therefore, any income must come from an outside source.

87 Railroad Retirement Act of 1937, 50 Stat. 307, as amended, 45 U.S.C. $\$ \$ 228 a-$ 228z-1 (Supp. I, 1965). Railroad workers are the only group of private employees with a retirement plan underwritten by the federal government. See generally Schotrland, op. cit. supra note 55, at 131-40.

8841 Stat. 614 (1920), as amended, 5 U.S.C. $\$ \$ 2251-68$ (Supp. I, 1965). This plan covers all federal employees with civil service status. Those without it are covered by OASDI.

89 In $1963,37.2 \%$ of OAA recipients were also receiving OASDI. Social Security Bull., 1963 Annual Statistical Supp., p. 13, table 15. Most of this overlap would be eliminated if the income of OASDI beneficiaries were raised by the matching payments. OAA should be changed to make the requirements of the various states more uniform. 
OASDI,,$^{90}$ the matching payment would be reduced one dollar for every four dollars of earned income between 1,500 and 2,700 dollars. ${ }^{91}$

This plan would only fill part of the existing gap between the BLS standards and the income of the aged. However, it must be recognized that the minimum income goal cannot be reached immediately, and the rate of progress will be determined by balancing it with other objectives of our society as determined by Congress and the Executive. The goal of a guaranteed income for the aged is a desirable one, and the proposal would be a big start toward fulfilling it.

By utilizing the machinery of the social security system, this plan provides the aged with the income they require in a way that will not make them feel that they are giving up part of their self-respect and independence. A second advantage of this program is that it will have very little detrimental effect on the incentive for self-saving. Most of the aged are already receiving OASDI benefits, and, since they will also receive payments under the proposed plan, there will not be any penalty in the form of lower matching payments because of self-saved assets.

Despite its use of the social security machinery, this plan is not OASDI in its present form-it is financed by direct government contributions rather than payroll taxes. This is partly from necessity because the payroll taxes required for such payments would be prohibitive and partly because of a belief that the populace as a whole, rather than just the labor force and their employers, has some responsibility in providing for the aged.

90 See note 58 supra.

91 The problem caused by the earnings test is illustrated by the following examples (assuming a retired single worker under seventy-two) :

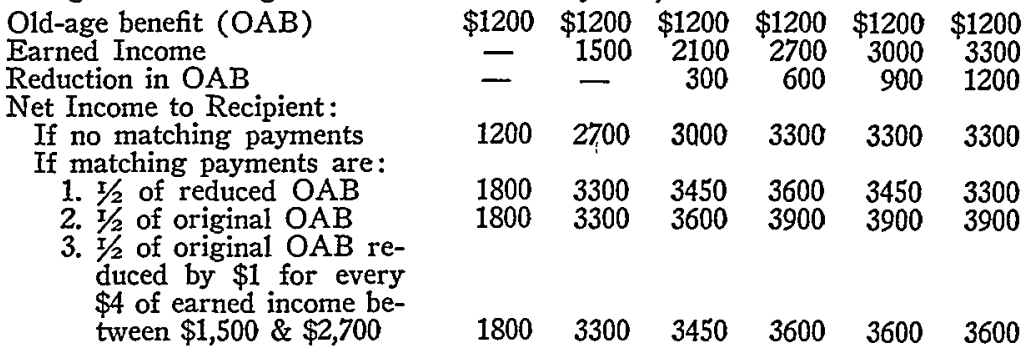

Proposal 3, the one advocated, steers a middle ground between the inequity of proposal 1 and the heavy cost of proposal 2. The philosophical justification for the earnings test is that there is no social necessity to make payments to those who continue working since the purpose of the retirement benefits is to replace income following withdrawal from employment. The practical justification for the test is that it keeps the costs of social security down. Prior to the 1965 amendments it was estimated that abolishment of the earnings test would cost $\$ 2$ billion. See Myers, supra note 58 , at $3-4,12$.

It is hard to accept the philosophical justification for the test because of the line it draws between earned income and investment income. Nevertheless, because the cost of repealing it is so great, although less than $\$ 2$ billion today because of the 1965 increases in the amount of allowed earnings, see note 58 sipra, on the whole it is deemed wiser to retain the test rather than decrease the chances for the passage of the matching payment program. Once the matching plan is established, the necessity and fairness of the earnings test could be reexamined. See also ten Broeck \& Wilson, supra note 63 , at 301 . 
Those aged persons not covered by OASDI and those whose payments under it are less than the minimum standards would receive direct assistance through the OAA program. This insures that those who probably need the income and most will receive it. ${ }^{22}$ One major disadvantage of this proposal - unnecessary aid to the wealthy-is for the most part negated by a later proposal to tax all social security benefits on receipt.

This proposal would avoid the complaint voiced about using the tax system for giving relief-that the aid given is secret, haphazard and not reflected in the annual budget, and moreover tends toward permanence because it is not subject to annual congressional review. ${ }^{93}$ The public would have full knowledge of the annual expenditures under this program. The plan should not be permanent in the sense that Congress could not either raise the level of matching payment if the cost of living for the aged increases or lower the level if it is shown that the incomes of the aged have increased to the point where so many of the aged have sufficient income that the matching payments are not needed. On the other hand, the level of payments should hopefully not become a political football.

The major drawback to enactment of this program is its heavy cost. The initial annual cost to the government of the matching payments would be approximately 7.8 billion dollars. ${ }^{94}$ However, a large part of the amount

92 It is also possible to write some procedural safeguards into the administrative machinery. See Reich, Individual Rights and Social Welfare: The Emerging Legal Issies, 74 YALE L.J. 1245, 1252-53 (1965).

93 See Wolfman, stipra note 82, at 183.

04 The estimate of $\$ 7.8$ billion is surely not an exact figure, but it is a fair approximation of the cost of the proposal. Following is a brief description of how the cost of the various component parts of the proposal were calculated.

1. OASDI Benefits:

The amount of the monthly benefits (as of September 1965) of the three OASDI benefits to be matched-old-age, wife's (including husband's) and widow's (including widower's) - was multiplied by a factor (12 months times $50 \%$ ) to give the annual amount of matching payments. See Social Security Bull., Jan. 1966, p. 50. A downward adjustment of $5 \%$ had to be made to the amount of wife's benefits to compensate for the inclusion in the September 1965 figures of benefits payable to wives under sixty-five with children. $5 \%$ was used because in 1963 that was approximately the percentage of total wife's benefits going to wives under sixty-five with children. See Social Security Bull., 1963 Annual Statistical Supp. p. 63, table 69.

The cost of matching OASDI benefits is thus:

$$
\text { Sept. } 1965
$$

$\begin{array}{lc}\text { Monthly Benefits } \\ \$ 920,960,000 \\ \text { OAB } & 107,999,000 \\ \text { Wife's (as adjusted) } & 167,823,000 \\ \text { Widow's } & \frac{167,25}{\$ 1,196,782,000} \text { times } 12 \text { months times } 50 \%=\$ 7,180,692,000\end{array}$

2. Railroad Retirement Benefits (RR Benefits) :

The number of recipients in current payment status as of June 30,1964, see 1964 RAILROAd RETIREMENT Bd. ANn. REP. 110-12, table B-I, was multiplied by the amount of average matching payments (AMP) to be made to recipients of similar OASDI benefits. The AMP's were calculated by multiplying the average benefit payments under OASDI in September 1965 (ABP), see Social Security Bull., Jan. 1966, p. 51, by twelve months and taking $50 \%$ of the resulting amount as the AMP:

Average $\mathrm{OAB}$ Benefit (rounded off) Average Wife's Benefit (50\%) Average Widow's Benefit
$A B P$

$\$ 84$

42

73.65
$A M P$

$\$ 504$

252

441.90 
would be recouped by the proposals made later to change certain tax pro-

94 (Continued)

The cost of matching $R R$ benefits is :

$\begin{array}{lcc} & 1964 \text { Recipients } & \text { AMP } \\ \text { Employees } & 423,228 & \$ 504 \\ \text { Wife's } & 173,682 & 252 \\ \text { Widow's } & 234,075 & 441.90\end{array}$

Total Matching

Payments (TMP)

$\$ 213,307,000$

$43,768,000$

$103,438,000$

$\$ 360,513,000$

3. Federal Civil Service Benefits (FCS Benefits) :

The number of annuitants as of June 30 , 1964, see BUREau of RETrREMant \& Insurance, U.S. Civil Service Comm., 1964 Annual Report, p. 7, table A-4, p. 11, table A-8, was multiplied by the proper AMP (there is no separate figure for wife recipients) :

\section{Employees Widows}

$$
\begin{gathered}
\text { AMP } \\
\$ 504 \\
441.90
\end{gathered}
$$

$T M P$

$\$ 242,994,000$

$71,062,000$

$\$ 314,056,000$

4. Payments Necessitated by Integrating Proposal with Earning Test (see note 91 supra):

In calculating the amounts of matching payments thus far, those whose benefits have been partially suspended because of the earnings test have been included at their full value. Because the decrease in the cost of matching payments due to the test proposed in note 91 supra is relatively insignificant, it is here disregarded.

Those whose benefits have been completely suspended because of the earnings test have not heretofore been considered. Under the test proposed in note 91 supra, each total suspendee will receive a full matching payment less $\$ 300$. The number of suspended beneficiaries was therefore multiplied by the AMP for their class less $\$ 300$. The number of suspended beneficiaries was calculated by multiplying the number of current beneficiaries in September 1965, see Social Security Bull., Jan. 1966, p. 49, adjusted by $7 \%$ for the approximate number of wives under sixty-five with children currently receiving benefits, see Social Security Bull., 1963 Annual Statistical Supp., p. 63 , table 69 , by the percentage of beneficiaries suspended in 1962. See Myers, supra note 58 , at 12 . The 1962 suspension figures are probably higher than current ones would be because the amount of allowable earnings has been increased since 1962 . See note 58 supra. The cost of this component part is :

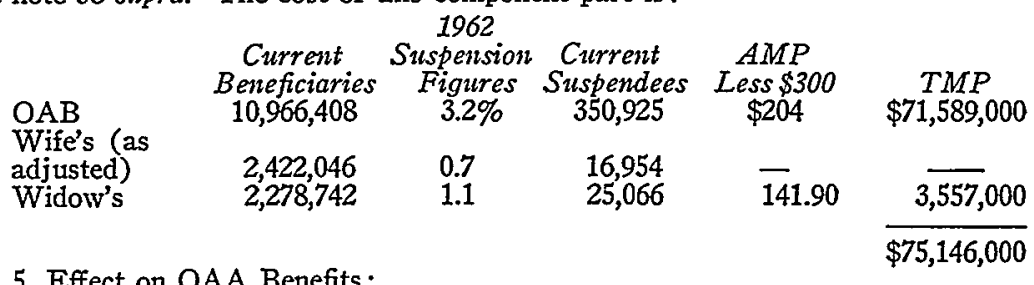

The number of current OAA recipients (September 1965) (Social Security Bull., Jan. 1966 , p. 55 , table $M-16$ ), reduced by $37.2 \%$ (see note 89 suspra) to compensate for the number of OAA recipients also receiving OASDI who, it is assumed, will no longer require OAA because of the matched OASDI payments, was multiplied by the average monthly OAA benefits paid in September 1965 (Social Security Bull., Jan. 1966, p. 55, Table M-16) (rounded off). The resultant figure, increased by $50 \%$ as per proposal, was multiplied by twelve to give the annual cost of all OAA payments. The cost was then compared to the total amount of OAA paid in 1964 , ibid., to give the net effect of the matching proposal on OAA.

Total OAA paid in 1964

Current OAA recipients

Less: Estimated OASDI Overlap

Annual average proposed payment $(\$ 120 /$ month)

Cost of proposed OAA

Net Decrease in cost of OAA

$\$ 2,044,744,000$

$2,140,175$

$1,344,030$

$\$ 1,440$ 
visions.95 Amounts may also be saved in other welfare programs, both state and federal, that will reduce the net national costs of this program. If the cost is deemed excessive, it would be possible to match payments at a lower percentage level while retaining the basic principle of matching.

\section{B. Changes in Related Tax Provisions}

All tax provisions which allow an exemption, a deduction or a credit should not operate inconsistently with the set national policy goals. If the plan to make matching payments through the social security system were adopted, the present tax scheme would have to be changed to lower the net cost to the revenues and to keep the wealthier aged from receiving a bonanza. It is proposed that the additional personal exemption and retirement income credit be repealed, that OASDI retirement benefits be taxed on receipt (with an exclusion for those benefits representing previously taxed contributions by the recipient) and that a new tax credit for those over sixty-five be enacted. The theory of the credit would be that no person over sixty-five should pay income tax if his adjusted gross income is less than a given maximum amount. If the plan were put into effect today, the minimum level would probably be the BLS figures-2,500 dollars for a couple and 1,800 dollars for a single person..$^{96}$

The present taxing scheme for these provisions is absurd. Aside from the fact that a credit is a much more precise tool than an exemption, ${ }^{97}$ the combination of the additional personal exemption, the exclusion of OASDI benefits and the standard deduction allow a couple over sixty-five to escape $\operatorname{tax}$ on 3,000 dollars plus their OASDI benefits, and a single person over sixty-five is not taxed on 1,600 dollars in addition to his OASDI benefits. While these amounts exclude most of the aged from paying tax, they also give unwarranted benefits to those with high incomes.

94 (Continued)

Summary of Initial Cost of Matching Proposal:

\begin{tabular}{lr} 
OASDI Benefits & $\$ 7,180,692,000$ \\
RR Benefits & $360,513,000$ \\
FCS Benefits & $314,056,000$ \\
Earnings Test & $75,146,000$ \\
\hline Initial Cash Outlay & $7,930,407,000$ \\
Decrease in OAA & $109,341,000$ \\
\multicolumn{1}{c}{ Total Initial Cost } & $\$ 7,821,066,000$
\end{tabular}

95 No proposals are made as to the source of the initial $\$ 7.8$ billion. Congress could raise taxes, cut back on other existing expenditures or borrow to finance this program.

86 This plan could also serve as an experiment to test the feasibility of the credit approach for other low-income groups.

$07 \mathrm{~A}$ credit gives the same dollar relief for all taxpayers but, expressed as percentage of tax liability, it is less favorable to higher bracket taxpayers than an exemption based on the taxpayer's marginal tax rate. 
A tax credit set at sixty-three dollars for a married person over sixtyfive and at 130 dollars for an unmarried person over sixty-five would guarantee, at present rates and assuming use of the standard deduction, that no person with income under the BLS levels would pay federal income tax. ${ }^{98}$ To blunt partially the apparent but unreal inequity ${ }^{99}$ of having the credit for a couple less than that of an unmarried person and to make the tax politically palatable, it would be wise to set the credit for a married person at one hundred dollars. Taxes due would be very close to what they are presently for couples until the higher income brackets were reached, although, for single persons taxes due would be slightly lower than they are presently until adjusted gross income reached the 5,700 dollar level. ${ }^{100}$ However, taxation of the increased social security benefits would push many of the aged into a higher income bracket which would mean a substantial increase in their taxes. ${ }^{101}$ No one with too low an income level would be deprived of needed

98

\section{Adjusted gross income \\ Standard deduction and personal exemptions}

Present tax

\begin{tabular}{cr} 
Married Couple & Single \\
$\$ 2,500$ & $\$ 1,800$ \\
1,600 & 900 \\
\hline 900 & 900 \\
126 & 130
\end{tabular}

90 The reason why the credit for a single person would exceed that for a married couple is that the $\$ 700$ difference between $\$ 2,500$ and $\$ 1,800$ is not taxable income to a married couple-but rather an extra $\$ 600$ personal exemption and an increase of $\$ 100$ in the standard deduction.

100

\section{Adjusted gross income Standard deduction and personal exemptions}

Taxable income

Tax

Credit

Net tax payable

\begin{tabular}{|c|c|}
\hline $\begin{array}{c}\text { Present } \\
\$ 5,700\end{array}$ & $\begin{array}{c}\text { Proposed } \\
\$ 5,700\end{array}$ \\
\hline 1,770 & 1,170 \\
\hline 3,930 & 4,530 \\
\hline 677 & 806 \\
\hline 一 & 130 \\
\hline 677 & 676 \\
\hline
\end{tabular}

101 For example, if a married taxpayer presently has $\$ 4,000$ of rental income and $\$ 2,000$ of social security benefits, his tax would be $\$ 140$. Under the proposed plan with the credit (but excluding consideration of matching payments) his tax would be computed as follows :

Rental income

Social security

Less : 22\% (see note 103 infra)

Adjusted gross income

Less : $10 \%$ standard deduction and personal exemptions

Taxable income

Tax

Less credit

Tax payable

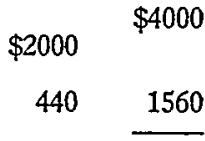

$\$ 5560$

1756 
dollars by taxes, while those who are now receiving unwarranted benefits would lose them.

Once it is decided to tax social security benefits on receipt, allowance should ${ }^{102}$ be given at some time for the employee's contributions which currently come from after-tax dollars. The alternatives are to grant an exclusion on receipt, ${ }^{103}$ or either a deduction or credit at the time of the contribution. The first alternative is preferred for two reasons: 1 ) it will result in a lower revenue loss because it will take a good number of years until the contributions of present workers come back to them as benefits, and the workers are generally paying tax at a higher marginal rate during their earning years; 2) there is a benefit in having the tax on the contributions paid currently when the worker is probably better able to bear it, giving him more cash income when he retires. These reasons outweigh the arguments in favor of a current deduction or credit that the employee should not be taxed on income he is forced to give up, ${ }^{104}$ and its corollary that since the employee may never receive any benefits from the system, if he is denied a current deduction, he may never enjoy it.

Even if the proposal to make the matching payments is not adopted, the recommended substitution of the tax credit for the additional personal exemption, the retirement income credit and the exclusion of social security benefits from taxable income should be undertaken. The inclusion of social security benefits in taxable income is an essential reform, but realistically there is little chance Congress would do so without a substantial increase in their amount as a political "bone" to the aged.105

The net revenue gain from adoption of these tax proposals would be

102 The principle of not taxing the return of capital is a long-established one. See Doyle v. Mitchell Bros. Co., 247 U.S. 179, 184-88 (1918). This does not mean Congress could not tax return of capital, but its practice of not doing so is justified on both policy and political grounds.

103 The operation of the exclusion for the return of capital invested in social security should be similar to the general rule of INT. REV. CODE OF 1954, \$72, concerning the taxation of annuities. The amount of employee contributions divided by the expected return from the Social Security Trust Fund (figured on the basis of mortality tables) gives an exclusion ratio which, when applied to the benefits received, determines the amount of benefits excluded from gross income.

In another context the Treasury has determined that $22 \%$ of social security benefits represent employee contributions. Treas. Reg. $\$ 1.401-3(\mathrm{e})(2)$ (1956). 357.

104 Munts, Social Security and the Personal Income Tax, 1 Compendrum 353,

105 President Kennedy's 1963 proposals included repeal of the additional personal exemption and the retirement income credit and their replacement by a $\$ 300$ per person tax credit. The credit was to be reduced by one-half the social security benefits received and multiplied by the taxpayer's highest marginal tax rate which theoretically compensated for the employer's contributions to social security. It was said that no couple with less than $\$ 5,800$ income or a single person with less than $\$ 2,900$ income would pay tax. The President's 1963 Tax Message, H.R. Doc. No. 43, 88th Cong., 1st Sess. 12-13 (1963). This program was completely rejected by Congress. 
approximately 3.4 billion dollars initially. ${ }^{108}$ This amount when matched against the initial government expenditure of 7.8 billion dollars nets to an initial cost of 4.4 billion dollars. ${ }^{107}$

108 The revenue recoupment was calculated as follows:

\begin{abstract}
Repeal of additional personal exemption (see note 77 supra)

Repeal of retirement income credit (see note 79 supra)

Taxation of certain retirement benefits

Matching payments to be made (see note 94 sispra)

Taxation of present benefits :

Certain social security bene-

fits (see note 94 supra)

Railroad Retirement (1964

RAILROAD RETIREMENT BD. ANN. ReP. 113)

(Federal Civil Service benefits are already taxed as an annuity. See Heard v. Commissioner, 326 F.2d 962 (8th Cir.), cert. denied, 377 U.S. 978 (1964))
\end{abstract}

\section{$\$ 14,361,384,000$}

$1,029,000,000 \quad 15,390,384,000$

Increase in tax base

Less: Previously taxed contributions (22\% of $\$ 15$ billion) (see Treas. Reg. 1.401-3(e)(2) (1956))

Applying marginal tax rate of $\$ 7,930,407,000$

\section{Reveme Gain}

$\$ 380,000,000$

$135,000,000$

$\frac{3,385,884,000}{19,934,907,000}$

$16 \%$ (based on present incomes, see text accompanying note 12 supra, plus matching payments and less exemptions and deductions)

$16 \%$

$\frac{3,189,585,000}{3,704,585,000}$

Increase in revenues

Less : Cost of tax credit

(The estimated cost of the 1963 proposed $\$ 300$ per person tax credit was $\$ 835$ million. The average proposed credit in this plan is approximately $\$ 115$ per person. 115/300 times $\$ 835$ million equals $\$ 320.8$ million.)

Total revenue recoupment:

This is a conservative estimate of the revenue recoupment. The actual marginal rate at which the benefits will be taxed may well exceed $16 \%$ because recipients of the higher dollar amounts of benefits, and hence higher matching payments also, will be those with the higher marginal tax rates.

107 More precise revenue and cost analyses of the proposals advocated will have to wait until the Treasury Department applies its more sophisticated tools to the problem. 


\section{Conclusion}

Inadequate income is the most pressing problem of the aged today. The proposal is to have the federal government, the only feasible source of this income, make payments through the existing social security machinery to alleviate the problem. The premise underlying this proposal is that no aged person should lack the income necessary for a "modest but adequate" standard of living. In conjunction with the government payments through OASDI a general tax credit for the aged should be substituted for the present combination of the additional personal exemption, the retirement income credit and the exclusion of social security benefits from taxable income. This last proposal would guarantee that no person with income below that necessary for a "modest but adequate" standard of living would pay income tax and at the same time would reduce the unwarranted benefits given the wealthier aged. 